\title{
Establishing the Validity and Reliability of the Malaysian English Language Textbook Evaluation Checklist (MELTEC) Using Rasch Measurement Model (RRM)
}

\author{
Faustina Roberts \\ Faculty of Education, National University of Malaysia (UKM), 43600 Bangi, Selangor, Malaysia \\ Azlina Abdul Aziz \\ Faculty of Education, National University of Malaysia (UKM), 43600 Bangi, Selangor, Malaysia \\ Mohd Effendi @ Ewan Mohd Matore \\ Faculty of Education, National University of Malaysia (UKM), 43600 Bangi, Selangor, Malaysia
}

\begin{abstract}
A textbook is an important teaching and learning material. Evaluating a textbook is essential to ensure educational goals are met. In the present study, the Malaysian English Language Textbook Evaluation Checklist (MELTEC) is developed for the purpose of materials adaptation. The lack of validity and reliability of previous textbook evaluation checklists reported by researchers in the field of ELT textbook evaluation has resulted in the need to establish the validity and reliability of the checklist developed in this study using the Rasch Measurement Model (RRM). One hundred and ten ESL secondary school teachers from Kuala Lumpur, Malaysia, had participated in this study. Rasch analysis was used to examine the item fit, polarity, reliability, separation index, and unidimensionality of the checklist. As a result, the finalised version of MELTEC comprises of 78 items. A total of 63 items were dropped as these items were not deemed to be suitable. The analysis performed using Rasch Measurement Model proved that the checklist has high validity and reliability. The checklist is found to be suitable to evaluate ELT secondary school textbooks in Malaysia. On that account, future researchers can consider using Rasch Measurement Model to establish the validity and reliability of the instruments developed to ensure their integrity and quality.
\end{abstract}

Index Terms - validity, reliability, textbook evaluation checklist, Rasch Measurement Model (RRM)

\section{INTRODUCTION}

A textbook will never be suitable for all teaching and learning situations despite how well it is written (Nguyen, 2015). Hence, textbook evaluation is pivotal to ensure educational goals are met. There are various methods to evaluate an ELT textbook, and the checklist method is one of the methods commonly employed. There are a number of advantages of using the checklist method. The most prominent advantage would be that it is economical and systematic (Cunningsworth, 1995; McGrath, 2002). Besides, the explicit criteria in a checklist allow for a thorough evaluation while reducing impressionistic judgment (Nimehchisalem \& Mukundan, 2013). Moreover, evaluators can also add, modify and adapt the criteria within a checklist to suit the context of evaluation (Mukundan \& Ahour, 2010; Demir \& Ertas, 2014). The ability to transform a textbook evaluation checklist to make it suitable for the context of evaluation, makes this method of evaluation unique. One of the purposes of a textbook evaluation checklist is to facilitate ESL teachers to make informed decisions on materials adaptation. Adaptation is when ESL teachers make partial or minor changes in a textbook in an attempt to make it suitable for a particular class or level (Nehal, 2016). Adaptations are necessary despite careful selection of textbooks (Halim \& Halim, 2017; McDonough, Shaw \& Masuhara, 2013). Despite how suitable learning materials are, they may not cater to the different needs, learning styles, and cultural norms of individual learners (Tomlinson, 2012).

Numerous textbook evaluation checklists have been developed by previous researchers, albeit these checklists may not be suitable for the Malaysian context. Evaluation criteria are best customised to suit a specific context to appeal for local use (Isik, 2018). Moreover, textbook evaluation checklists in the past suffer from context-sensitivity (Simsek \& Dündar, 2018). These checklists used items in their predecessors or were reworded or reclassified to a more practical version. They may not reflect the actual picture of a textbook and meet the preference of the end-users. Nimehchisalem and Mukundan (2015) also argue that checklists in the literature lack validity and reliability. On record, there are also only a few studies that test the efficiency of the checklists developed (Mukundan \& Ahour, 2010; Isik, 2018). Therefore, the Malaysian English Language Textbook Evaluation Checklist (MELTEC) was developed in the present study to 
evaluate the ELT textbooks used for the teaching and learning of English in secondary schools. The checklist is to be used by ESL teachers in the secondary schools in Malaysia for materials adaptation. As aforementioned, the literature highlights the lack of validity and reliability of the textbook evaluation checklists developed in the past. On that account, to establish the reliability and validity of MELTEC, a series of methods are employed, among which is the Rasch Measurement Model. The Rasch Measurement Model, a one-parameter Item Response Theory (IRT), is a modern model of measurement often used in the social sciences. The weaknesses of methods of analysis that fall under the Critical Test Theory (CTT), such as the Exploratory factor analysis (EFA) and Confirmatory factor analysis (CFA) in determining validity and reliability, lead to the reason the Rasch Measurement Model was chosen in the present study.

The Rasch Measurement Model has been the center of attention by various researchers worldwide in which their interest lies in building and constructing new instruments. The model by Georg Rasch is often a preferred choice among researchers due to the advantages that constructs, such as linearity, independence, objectivity, comprehensiveness, and inferences, can be easily deduced (Wright \& Stone, 1979). This model advocates that response towards an item is solely influenced by an individual's ability and item difficulty (Bond \& Fox, 2015). Rasch model ascertains that each item is only constructed based on the parameter of difficulty. An individual may have a 50:50 chance of attempting the items correctly given the difficulty logits of 0.00 . Consequently, it is to be accepted that when the item difficulty is increased, the chances of success will be affected and in this case decreased. The order of evaluation within the model may vary according to the needs of a particular study. Under the Rasch Measurement Model, there are eight diagnostic data analyses involved in the process of instrument development, which include (i) unidimensional; (ii) compatibility (fit) item; (iii) polarities item; (iv) reliability and separation item respondents; (v) appropriateness of the measurement scale based on the use of categories; (vi) value of standardised residual correlation in determining leaning item; (vii) differential items functioning (DIF) based on gender; and (viii) the distribution of item difficulty levels and abilities of respondents (Hassan, 2012). However, based on the objective and needs of the present study, the following areas of analysis are performed using the Rasch Measurement Model; (i) item fit; (ii) item polarity (iii) reliability and separation index and (iv) unidimensionality. These analyses are sufficient to establish the validity and reliability of MELTEC. The following section discusses the area of analysis performed in the present study.

\section{Methodology}

In the present study, the prototype MELTEC was refined by fifteen professional and lay experts using the Fuzzy Delphi Method (FDM) before employing the Rasch Measurement Model. These experts validated a total of 204 items. After the validation process, the number of items was reduced to 141. During the analysis, 63 items did not meet the requirements of the Fuzzy Delphi Method. On that account, these items were dropped. All 141 items were then refined to ensure their face validity. For this purpose, ten professional and lay experts were appointed to assess the prototype checklist's overall presentation and to determine if the respondents of the study will easily understand the items. The items were refined accordingly before the Pilot study was conducted. The prototype Malaysian English Language Textbook Evaluation Checklist distributed during the Pilot study consisted of 141 items anchored in a 7-point Likert scale (1= Strongly Disagree, 2= Disagree, 3= Somewhat disagree, 4= Neither Agree nor Disagree, 5= Somewhat agree, 6=Agree, $7=$ Strongly Agree). The 7-point Likert scale was chosen due to the accuracy and precision of data obtained (Jamil et al., 2019). The prototype checklist was distributed to 110 ESL secondary school teachers in Kuala Lumpur, Malaysia. These ESL secondary school teachers analysed the Pulse 2 ELT textbook by Macmillan Press using the prototype checklist. They were given one week to complete the checklists, after which the checklists were collected for analysis using the Rasch Measurement Model.

\section{FINDINGS}

To establish the validity and reliability of MELTEC using the Rasch Measurement Model, the analyses of item fit, item polarity, reliability, separation index and unidimensionality were performed using WINSTEPS 3.71 software. Table 1 presents the rule of thumb set for analysing the items in this study. The items that do not meet the rule of thumb set will be dropped. The remaining items will make up MELTEC. 
TABLE 1

RULE OF THUMB SET FOR ITEM ANALYSIS USING RASCH MEASUREMENT MODEL (RMM)

\begin{tabular}{|l|l|}
\hline Statistical Information & Rule of thumb \\
\hline $\begin{array}{l}\text { Item Fit } \\
\text { MNSQ (Infit and Outfit) }\end{array}$ & $0.6-1.4$ (Bond \& Fox, 2015). \\
\hline Item Polarity (PT- Measure Correlation) & $0.3-0.8$ (Bond \& Fox, 2015). \\
\hline $\begin{array}{l}\text { Unidimensionality } \\
\text { Principal Component Analysis (PCA) } \\
\text { Noise }\end{array}$ & $\begin{array}{l}>20 \% \text { (Reckase, 1979) } \\
<10 \% \text { (Fisher, 2007) }\end{array}$ \\
\hline $\begin{array}{l}\text { Reliability } \\
\text { Item }\end{array}$ & $>0.8$ (Fisher, 2007) \\
\hline $\begin{array}{l}\text { Person } \\
\begin{array}{l}\text { Item } \\
\text { Person }\end{array}\end{array}$ & $>2.0$ (Linacre, 2002) \\
\hline
\end{tabular}

\section{A. Item Fit and Polarity}

In the present study, the Infit and Outfit Mean Square Analysis (MNSQ) were analysed to measure the item fit of items in the prototype checklist. The infit and outfit MNSQ values should be between 0.6 and 1.4 (Bond \& Fox, 2015). Also, the Point Measure Correlation (PTMEA Corr.) values were examined to detect the extent to which the constructs in the checklist achieve their intended goal. Therefore, to determine if the items in the checklist measure the constructs, the PTMea Correlation values must be positive and between the value of 0.3 and 0.8 (Bond \& Fox, 2015). Table 2 displays the Infit, Outfit Mean Square Analysis (MNSQ) and Point Measure Correlation (PTMEA Corr.) values of all the 141 items in the prototype Malaysian English Language Textbook Evaluation Checklist. These items were first analysed for item fit. After the analysis for item fit was performed, the analysis for item polarity was performed. The items that did not fit the rule of thumb for item fit and item polarity were dropped. Based on the analyses performed, 63 items were not in the specified range of the analyses performed. Hence, these items were dropped.

TABLE 2

ITEM STATISTICS: ITEM FIT AND POLARITY

\begin{tabular}{|c|c|c|c|c|}
\hline Item & $\begin{array}{c}\text { Infit } \\
\text { (MNSQ) }\end{array}$ & $\begin{array}{c}\text { Outfit } \\
\text { (MNSQ) }\end{array}$ & PT- Measure Corrrelation & Result \\
\hline 1 & .77 & .81 & .16 & Dropped \\
\hline 2 & .76 & .78 & .24 & Dropped \\
\hline 3 & 1.22 & 1.23 & .22 & Dropped \\
\hline 4 & 1.32 & 1.42 & .51 & Dropped \\
\hline 5 & 1.36 & 1.45 & .51 & Dropped \\
\hline 6 & 1.35 & 1.48 & .49 & Dropped \\
\hline 7 & .55 & .55 & .62 & Dropped \\
\hline 8 & 1.59 & 1.68 & .22 & Dropped \\
\hline 9 & 1.65 & 1.76 & .29 & Dropped \\
\hline 10 & 1.79 & 1.93 & .27 & Dropped \\
\hline 11 & .72 & .76 & .51 & Retain \\
\hline 12 & 1.31 & 1.57 & .28 & Dropped \\
\hline 13 & .82 & .73 & .48 & Retain \\
\hline 14 & 1.53 & 1.68 & .37 & Dropped \\
\hline 15 & 1.35 & 1.51 & .37 & Dropped \\
\hline 16 & 1.06 & 1.33 & -.02 & Dropped \\
\hline 17 & 1.35 & 1.53 & .21 & Dropped \\
\hline 18 & .63 & .64 & .52 & Retain \\
\hline 19 & .67 & .67 & .49 & Retain \\
\hline 20 & 1.12 & 1.27 & .48 & Retain \\
\hline 21 & 1.42 & 1.73 & .33 & Dropped \\
\hline 22 & 1.03 & 1.10 & .40 & Retain \\
\hline 23 & 1.43 & 1.78 & .36 & Dropped \\
\hline 24 & 1.42 & 1.73 & .33 & Dropped \\
\hline 25 & .80 & .85 & .55 & Retain \\
\hline 26 & .99 & 1.10 & .45 & Retain \\
\hline 27 & .84 & .79 & .55 & Retain \\
\hline 28 & 1.36 & 1.66 & .45 & Dropped \\
\hline 29 & 1.26 & 1.55 & .44 & Dropped \\
\hline 30 & 1.25 & 1.59 & .39 & Dropped \\
\hline Item & $\begin{array}{c}\text { Infit } \\
\text { (MNSQ) }\end{array}$ & $\begin{array}{c}\text { Outfit } \\
\text { (MNSQ) }\end{array}$ & PT- Measure Corrrelation & Result \\
\hline 31 & 1.07 & 1.36 & .46 & Retain \\
\hline 32 & .44 & .44 & .52 & Dropped \\
\hline 33 & .75 & .66 & .67 & Retain \\
\hline 34 & .64 & .57 & .58 & Dropped \\
\hline 35 & .87 & .86 & .48 & Retain \\
\hline
\end{tabular}




\begin{tabular}{|c|c|c|c|c|}
\hline 36 & 1.25 & 1.59 & .39 & Dropped \\
\hline 37 & 1.14 & 1.34 & .38 & Retain \\
\hline 38 & 1.36 & 1.45 & .51 & Dropped \\
\hline 39 & .90 & .98 & .48 & Retain \\
\hline 40 & .95 & 1.05 & .56 & Retain \\
\hline 41 & .81 & .85 & .65 & Retain \\
\hline 42 & .87 & .87 & .54 & Retain \\
\hline 43 & .87 & .91 & .53 & Retain \\
\hline 44 & 1.14 & 1.51 & .39 & Dropped \\
\hline 45 & .83 & .76 & .63 & Retain \\
\hline 46 & .70 & .68 & .57 & Retain \\
\hline 47 & .68 & .61 & .59 & Retain \\
\hline 48 & .71 & .60 & .55 & Retain \\
\hline 49 & .64 & .57 & .58 & Dropped \\
\hline 50 & .93 & .89 & .55 & Retain \\
\hline 51 & 1.61 & 1.75 & .44 & Dropped \\
\hline 52 & 1.52 & 1.64 & .41 & Dropped \\
\hline 53 & .86 & .80 & .47 & Retain \\
\hline 54 & .63 & .64 & .52 & Retain \\
\hline 55 & .95 & 1.09 & .46 & Retain \\
\hline 56 & .73 & .67 & .57 & Retain \\
\hline 57 & .55 & .53 & .61 & Dropped \\
\hline 58 & .91 & 1.09 & .48 & Retain \\
\hline 59 & .94 & 1.16 & .50 & Retain \\
\hline 60 & .79 & .77 & .59 & Retain \\
\hline 61 & .67 & .71 & .65 & Retain \\
\hline 62 & .85 & .87 & .54 & Retain \\
\hline 63 & .74 & .81 & .57 & Retain \\
\hline 64 & 1.41 & 1.53 & .53 & Dropped \\
\hline 65 & 1.36 & 1.45 & .51 & Dropped \\
\hline 66 & 1.06 & 1.08 & .43 & Retain \\
\hline 67 & 1.21 & 1.43 & .33 & Dropped \\
\hline 68 & 1.27 & 1.45 & .37 & Dropped \\
\hline 69 & .88 & .98 & .29 & Dropped \\
\hline 70 & 1.27 & 1.41 & .42 & Dropped \\
\hline 71 & .85 & .92 & .54 & Retain \\
\hline 072 & .88 & .87 & .47 & Retain \\
\hline 73 & .76 & .75 & .53 & Retain \\
\hline 74 & 1.03 & 1.11 & .36 & Retain \\
\hline 75 & .72 & .78 & .56 & Retain \\
\hline 76 & 1.79 & 1.93 & .27 & Dropped \\
\hline 77 & .65 & .62 & .48 & Retain \\
\hline 78 & .66 & .66 & .39 & Retain \\
\hline 79 & .67 & .68 & .54 & Retain \\
\hline 80 & .65 & .62 & .49 & Retain \\
\hline 81 & .89 & .95 & .30 & Retain \\
\hline 82 & .65 & .64 & .41 & Retain \\
\hline 83 & 1.75 & 1.92 & .09 & Dropped \\
\hline 84 & .79 & .86 & .36 & Retain \\
\hline 85 & 1.35 & 1.53 & .29 & Dropped \\
\hline 86 & 1.36 & 1.54 & 3.7 & Dropped \\
\hline 87 & .67 & .67 & .43 & Retain \\
\hline 88 & .82 & .85 & .47 & Retain \\
\hline 89 & 1.36 & 1.54 & .26 & Dropped \\
\hline 90 & 1.27 & 1.41 & .42 & Dropped \\
\hline 91 & .71 & .83 & .32 & Retain \\
\hline 92 & .64 & .76 & .41 & Retain \\
\hline 93 & .66 & .72 & .41 & Retain \\
\hline 94 & .68 & .75 & .43 & Retain \\
\hline 95 & .58 & .61 & .43 & Dropped \\
\hline 96 & .55 & .53 & .61 & Dropped \\
\hline 97 & .80 & .77 & .44 & Retain \\
\hline 98 & .75 & .73 & .39 & Retain \\
\hline 99 & .80 & .76 & .50 & Retain \\
\hline 100 & .78 & .78 & .55 & Retain \\
\hline Item & $\begin{array}{c}\text { Infit } \\
(\text { MNSQ) }\end{array}$ & $\begin{array}{c}\text { Outfit } \\
\text { (MNSQ) }\end{array}$ & PT- Measure Corrrelation & Result \\
\hline 101 & 1.60 & 1.71 & .23 & Dropped \\
\hline 102 & 1.43 & 1.56 & .23 & Dropped \\
\hline 103 & 1.26 & 1.32 & .27 & Dropped \\
\hline 104 & 1.43 & 1.56 & .23 & Dropped \\
\hline 105 & .94 & 1.16 & .50 & Retain \\
\hline
\end{tabular}




\begin{tabular}{|c|c|c|c|c|}
\hline 106 & .86 & .87 & .56 & Retain \\
\hline 107 & .88 & .93 & .51 & Retain \\
\hline 108 & .88 & .93 & .24 & Dropped \\
\hline 109 & .60 & .55 & .60 & Dropped \\
\hline 110 & .55 & .53 & .61 & Dropped \\
\hline 111 & .95 & 1.01 & .38 & Retain \\
\hline 112 & .55 & .52 & .45 & Dropped \\
\hline 113 & .47 & .47 & .50 & Dropped \\
\hline 114 & .51 & .51 & .43 & Dropped \\
\hline 115 & .59 & .54 & .46 & Dropped \\
\hline 116 & .55 & .57 & .53 & Dropped \\
\hline 117 & .51 & .51 & .43 & Dropped \\
\hline 118 & .90 & 1.03 & .35 & Retain \\
\hline 119 & .94 & .91 & .35 & Retain \\
\hline 120 & .94 & .94 & .48 & Retain \\
\hline 121 & .83 & .80 & .40 & Retain \\
\hline 122 & .86 & .84 & .36 & Retain \\
\hline 123 & .83 & .82 & .43 & Retain \\
\hline 124 & .78 & .77 & .42 & Retain \\
\hline 125 & 1.09 & 1.12 & .30 & Retain \\
\hline 126 & 1.12 & 1.27 & .48 & Retain \\
\hline 127 & 1.35 & 1.53 & .21 & Dropped \\
\hline 128 & .85 & .97 & .37 & Retain \\
\hline 129 & .44 & .44 & .52 & Dropped \\
\hline 130 & .71 & .82 & .42 & Retain \\
\hline 131 & .72 & .78 & .47 & Retain \\
\hline 132 & .68 & .69 & .43 & Retain \\
\hline 133 & 1.25 & 1.59 & .39 & Dropped \\
\hline 134 & 1.36 & 1.45 & .51 & Dropped \\
\hline 135 & .67 & .73 & .33 & Retain \\
\hline 136 & .81 & .84 & .45 & Retain \\
\hline 137 & .81 & .90 & .41 & Retain \\
\hline 138 & .62 & .64 & .48 & Retain \\
\hline 139 & 1.38 & 1.49 & .52 & Dropped \\
\hline 140 & 1.36 & 1.45 & .51 & Dropped \\
\hline 141 & .80 & .80 & .47 & Retain \\
\hline
\end{tabular}

\section{B. Reliability and Separation Index}

Table 3 shows the person reliability and separation index values. The person reliability value obtained was 0.96 . The value of person reliability of more than .94 indicates excellent reliability (Fisher, 2007). This indicates that MELTEC would remain consistent if given to a new set of samples with the same characteristics as the samples in this study (Kamis et al., 2015). Meanwhile, the value of person separation index was 4.86 which is higher than 2, therefore, it is acceptable (Linacre, 2002; Fox \& Jones, 1998). This value indicates the levels of capabilities identified in the sample group. On the other hand, based on Table 4, the item reliability obtained was 0.92 . Fisher (2007) considers it to be very good. The value of the item separation index was 3.31, which exceeded the cut-off point of 2 (Linacre, 2002), indicating good separation of item difficulty level. On the whole, the values obtained prove that MELTEC is effective with a high level of reliability in terms of person and item.

TABLE 3

PERSON RELIABILITY AND SEPARATION INDEX

\begin{tabular}{|c|c|c|c|c|c|c|c|c|}
\hline \multirow{2}{*}{\multicolumn{2}{|c|}{$\begin{array}{l}\text { Total } \\
\text { Score }\end{array}$}} & \multirow{3}{*}{$\begin{array}{c}\text { Count } \\
140.6 \\
\end{array}$} & \multirow{3}{*}{$\begin{array}{c}\text { Measure } \\
.71 \\
\end{array}$} & \multirow{3}{*}{$\begin{array}{c}\begin{array}{c}\text { Model } \\
\text { Error }\end{array} \\
.12 \\
\end{array}$} & \multicolumn{2}{|c|}{ Infit } & \multicolumn{2}{|c|}{ Outfit } \\
\hline & & & & & \multirow{2}{*}{$\begin{array}{c}\text { MNSQ } \\
1.08\end{array}$} & \multirow{2}{*}{$\begin{array}{c}\text { ZSTD } \\
-.2 \\
\end{array}$} & \multirow{2}{*}{$\begin{array}{c}\text { MNSQ } \\
1.04\end{array}$} & \multirow{2}{*}{$\begin{array}{c}\text { ZSTD } \\
-.5 \\
\end{array}$} \\
\hline MEAN & 517.7 & & & & & & & \\
\hline S.D & 49.0 & .9 & .72 & .02 & .80 & 3.7 & .81 & 3.8 \\
\hline MAX. & 633.0 & 141.0 & 3.12 & .16 & 6.14 & 9.9 & 6.01 & 9.9 \\
\hline MIN. & 313.0 & 134.0 & -1.30 & .09 & .14 & -8.2 & .12 & -8.6 \\
\hline REAL I & $\mathrm{E} \quad .15$ & TRUE SD & .71 & SEPARA & 4.86 & \multicolumn{2}{|c|}{ Person RELIABILIT } & .96 \\
\hline $\begin{array}{l}\text { MODEL } \\
\text { S. E. OF F }\end{array}$ & $\begin{array}{l}\text { E } .12 \\
\text { n MEAN }\end{array}$ & TRUE SD & .71 & SEPARA & 5.74 & \multicolumn{2}{|c|}{ Person RELIABILITY } & .97 \\
\hline
\end{tabular}


TABLE 4

ITEM RELIABILITY AND SEPARATION INDEX

\begin{tabular}{|c|c|c|c|c|c|c|c|c|}
\hline \multirow{2}{*}{\multicolumn{2}{|c|}{$\begin{array}{l}\text { Total } \\
\text { Score }\end{array}$}} & \multirow{3}{*}{\begin{tabular}{|c|} 
Count \\
108.9
\end{tabular}} & \multirow{3}{*}{$\begin{array}{c}\text { Measure } \\
-.12\end{array}$} & \multirow{3}{*}{$\begin{array}{c}\begin{array}{c}\text { Model } \\
\text { Error }\end{array} \\
.14\end{array}$} & \multicolumn{2}{|c|}{ Infit } & \multicolumn{2}{|c|}{ Outfit } \\
\hline & & & & & \multirow{2}{*}{$\begin{array}{c}\text { MNSQ } \\
.82\end{array}$} & \multirow{2}{*}{$\begin{array}{c}\text { ZSTD } \\
-1.1\end{array}$} & \multirow{2}{*}{$\begin{array}{c}\text { MNSQ } \\
.86\end{array}$} & \multirow{2}{*}{$\begin{array}{c}\text { ZSTD } \\
-.8\end{array}$} \\
\hline MEAN & 410.9 & & & & & & & \\
\hline MAX. & 450.0 & 110.0 & 1.55 & .18 & 1.14 & .9 & 1.36 & 2.0 \\
\hline MIN. & 285.0 & 107.0 & -1.35 & .10 & .62 & -2.6 & .60 & -2.4 \\
\hline
\end{tabular}

\section{Unidimensionality}

In order to determine the measurement alignment of constructs, the unidimensionality features are analysed (Maat et al., 2018). The raw variance explained by measures and unexplained variance in the first construct were considered for this study. The analyses revealed that the value of raw variance explained by measures was $29.4 \%$. It exceeded the minimum requirement of $20 \%$ (Reckase, 1979). Also, the unexplained variance in the 1 st construct was $8.8 \%$. The value is proven to be less than $15 \%$ which indicates a good value (Fisher, 2007). Hence, the Malaysian English Language Textbook Evaluation Checklist items are proven to be accurate and fit the intended purpose of evaluating ELT textbooks.

TABLE 5

RESIDUAL PRINCIPAL COMPONENT ANALYSIS (PCA)

\begin{tabular}{|c|c|}
\hline Raw Variance Explained By Measures & Unexplained Variance In 1st Contrast \\
\hline $29.4 \%$ & $8.8 \%$ \\
\hline
\end{tabular}

\section{DISCUSSION}

After performing the data analyses in the present study following the benchmark and conditions of Rasch Measurement Model, 63 items in the prototype checklist were excluded. These items did not perform their function to measure the variables in this study. After excluding these items, the finalised version of the Malaysian English Language Textbook Evaluation Checklist consists of 78 items. The use of Rasch Measurement Model in the present study provided empirical evidence to prove the quality of items in the checklist. The summary of items dropped and retained is shown in Table 6.

TABLE 6

SUMMARY OF ITEMS DROPPED AND RETAINED

\begin{tabular}{|c|c|c|}
\hline Phase & No. of items & Items Dropped \\
\hline 1 (Design and Development) & 204 & 0 \\
\hline 2 (Validation) & 141 & 63 \\
\hline TOTAL & 78 & - \\
\hline
\end{tabular}

With the emergence of the Rasch Measurement Model, significant contributions to various fields of research have been recorded (Aryadoust, Tan \& Ng, 2019). However, the application of the Rasch Measurement Model in the field of ELT textbook evaluation, particularly in the development and validation of ELT textbook evaluation checklists is nonexistent. Previous textbook evaluation checklists have utilised the Critical Test Theory (CTT) to determine the validity and reliability of the instruments developed (Nguyen, 2015; Isik, 2018; Simsek \& Dündar, 2018; Nimehchisalem \& Mukundan, 2015; AbdelWahab, 2013; Karamifar, Barati, \& Youhanaee, 2014; Lopez Medina, 2016; Zokaeieh et al., 2019; Sahin, 2020). None up to date studies have considered employing Rasch Measurement Model, an Item Response Theory (IRT), to establish the psychometric properties of the items and the validity and reliability of the instruments developed. As aforementioned, textbook evaluation checklists in the past lack validity and reliability (Nimehchisalem \& Mukundan, 2015). Hence, by employing the Rasch Measurement Model in the present study, the validity and reliability of the Malaysian English Language Textbook Evaluation Checklist (MELTEC) have been established.

\section{CONCLUSION}

The analyses performed employing the Rasch Measurement Model to establish the validity and reliability of the Malaysian English Language Textbook Evaluation Checklist (MELTEC) have bridged the gap between research and practice. The examination of validity and reliability in this study provides an alternative for future researchers in the field of ELT textbook evaluation to consider establishing the validity and reliability of instruments developed using the Item Response Theory (IRT) instead of the Critical Test Theory (CTT) model of measurement. The aspects of validity and reliability are undoubtedly essential and should not be compromised, especially when developing a new research instrument. In essence, the assumptions fulfilled in this study using the Rasch Measurement Model were; Item Fit, 
Polarity, Reliability, Separation Index, and Unidimensionality. Through this paper, researchers especially in the language area can develop a new understanding of the integration of Rasch Measurement Model which is relatively under-studied especially in the field of ELT textbook evaluation. Furthermore, there are a total of eight diagnostic data analyses that can be performed using the Rasch Measurement Model, which includes (i) unidimensional; (ii) compatibility (fit) item; (iii) polarities item; (iv) reliability and separation item respondents; (v) appropriateness of the measurement scale based on the use of categories; (vi) value of standardised residual correlation in determining leaning item; (vii) differential items functioning (DIF) based on gender; and (viii) the distribution of item difficulty levels and abilities of respondents. Hence, future researchers may consider exploring other assumptions of the Rasch Measurement Model not explored in this study that would suit the objectives and purpose of their study.

\section{ACKNOWLEDGMENTS}

The researchers would like to thank the National University of Malaysia (UKM) for its support for this research via its Grant Tabung Agihan Penyelidikan (TAP-K017393).

\section{REFERENCES}

[1] AbdelWahab, M. M. (2013). Developing an English Language Textbook Evaluative Checklist. Journal of Research \& Method in Education, 1(3), 55-70.

[2] Aryadoust, V., Tan, H. A. H., \& Ng, L. Y. (2019). A Scientometric Review of Rasch Measurement: The Rise and Progress of a Specialty. Frontiers in Psychology, 10(2197), 1-16.

[3] Bond, T. G., \& Fox, C. M. B. (2015). Applying the Rasch: Fundamental measurement in the Human Sciences (Third Edition). New York: Routledge.

[4] Cunningsworth, A. (1995). Choosing Your Coursebook (Handbooks for the English Classroom). Oxford: Macmillan Heinemann.

[5] Demir, Y., \& Ertas, A. (2014). A suggested eclectic checklist for ELT coursebook evaluation. The Reading Matrix, 14(2), 243252.

[6] Fisher, W. P. (2007). Rating scale instrument quality criteria. Rasch Measurement Transactions, 21(1), 1095.

[7] Fox, C. M., \& Jones, J. A. (1998). Uses of Rasch Modeling in Counseling Psychology Research. Journal of Counseling Psychology, 45(1), 30-45.

[8] Halim, S., \& Halim, T. (2016). Adapting Materials: Revisiting the Needs of Learners. International Journal of Humanities and Cultural Studies, 2(4), 633-642.

[9] Hassan, A. B. (2012). Instrumen Penilaian Pembimbing Dalam Pelaksanaan Pembelajaran Berasaskan Kerja Pelajar Di Industri. [Unpublished Ph.D. dissertation], Universiti Teknologi Malaysia.

[10] Işik, A. (2018). ELT Materials Evaluation: A System and Criteria. Theory and Practice in Language Studies, 8(7), 797-812.

[11] Jamil, M. R. B. M., Siraj, S. B., Hussin, Z. B., Noh, N. R. B. M., \& Sapar, A. A. B. (2019). Pengenalan Asas Kaedah Fuzzy Delphi: Dalam Penyelidikan Reka Bentuk Pembangunan (Third Edit). Minda Intelek Agency.

[12] Kamis, A., Bakar, A. R., Hamzah, R., Soaib A., \& Zaliza, H. (2015). Using Rasch model and confirmatory factor analysis to assess instrument for clothing fashion design competency. International Journal of Social Science and Humanity, 5(5), 418421.

[13] Karamifar, M., Barati, H., \& Youhanaee, M. (2014). Local Evaluation Criteria for Global Textbooks: A Case Study from Iran. Theory and Practice in Language Studies, 4(5), 923-930.

[14] Linacre, J. (2002). Understanding Rasch measurement: Optimizing Rating Scale Category Effectiveness. Journal of Applied Measurement, 3, 85-106.

[15] Lopez Medina, B. (2016). Developing a CLIL textbook evaluation checklist. Latin American Journal of Content \& Language Integrated Learning, 9(1), 159-173.

[16] Maat, S. M., Effendi, M. E., Affandi, H. M., \& Mohamed, S. (2018). Psychometric evidence of statistical self-efficacy instrument based on postgraduate. International Journal of Advanced and Applied Sciences, 5(11), 95-99.

[17] McDonough, J., Shaw, C., \& Masuhara, H. (2013). Materials and Methods in ELT: A Teacher's Guide (Third Edit). West Sussex: Wiley-Blackwell.

[18] McGrath, I. (2002). Materials Evaluation and Design for Language Teaching. Edinburgh: Edinburgh University Press.

[19] Mukundan, J., \& Ahour, T. (2010). A review of Textbook Evaluation Checklist across Four Decades (1970-2008). In Tomlinson, B. \& Mahasura, H. (Eds.). Research for Materials Development in Language Learning: Evidence for best practice (pp. 336-352). Continuum International Publishing.

[20] Nehal, R. (2016). Materials Adaptation in English Language Teaching: Implications for Teacher Development. In Rahman, M. M. (Ed.) (2016). Integrating Technology and Culture: Strategies and Innovations in ELT (pp. 239-262), Anubhav Publishing House: India.

[21] Nguyen, C. (2015). An Evaluation of the Textbook English 6: A case study from secondary schools in the Mekong Delta Provinces of Vietnam. [Unpublished Ph.D. dissertation], University of Sheffield.

[22] Nimehchisalem, V., \& Mukundan, J. (2013). Usefulness of the English Language Teaching Textbook Evaluation Checklist. Pertanika Journal of Social Sciences and Humanities, 21(2), 797-816.

[23] Nimehchisalem, V., \& Mukundan, J. (2015). Refinement of the English Language Teaching Textbook Evaluation Checklist. Pertanika Journal of Social Sciences and Humanities, 23(4), 761-780.

[24] Reckase, M. D. (1979). Unifactor Latent Trait Models Applied to Multifactor Tests: Results and Implications. Journal of Educational and Behavioral Statistics, 4(3), 207-230.

[25] Sahin, S. (2020). Developing a Checklist for English Language Teaching Course book Analysis. International Journal of 
Education and Research, 8(1), 107-120.

[26] Simsek, M., \& Dündar, E. (2018). Particularised Checklists in Materials Evaluation: Developing Contextually Relevant Criteria for Turkish EFL Classes. Journal of Language and Linguistic Studies, 14(3), 154-189.

[27] Tomlinson, B. (2012). Materials development for language learning and teaching. Language Teaching, 45(2), $143-179$.

[28] Wright, B. D., \& Stone, M. H. (1979). Best Test Design. MESA Press: Chicago, IL

[29] Zokaeieh, S., Karimi, S. N., Nouri, F., \& Hakimzadeh, A. (2019). Developing a Critical Checklist for Textbook Evaluation. The Journal of English Language Pedagogy and Practice, 12(24), 202-225.

Faustina Roberts is currently pursuing her Ph.D. (TESL) at the Faculty of Education, National University of Malaysia. Her research interests include ELT materials development, textbook evaluation, and instrument development. Email: tinaroberts716@gmail.com

Azlina Abdul Aziz is a TESL lecturer at the Faculty of Education, National University of Malaysia. She has an Ed.D in Teaching of English from Teachers College, Columbia University, U.S.A. Her research interests include Teaching and Learning of Literature and Teacher Education in TESL. She is also interested in how literary texts and personal narratives may help students examine the social, cultural, and political issues in a particular context. Email: azlina1@ukm.edu.my

Mohd Effendi @ Ewan Mohd Matore is a senior lecturer at the Faculty of Education, National University of Malaysia. He obtained his Ph.D. (Psychometric and Evaluation) from Universiti Sains Malaysia, USM, Malaysia. His research interests include psychometric and evaluation, educational measurement, and instrument development. Email: effendi@ukm.edu.my 